\title{
Introduction: Skepticism in India
}

\author{
Ethan Mills \\ Department of Philosophy \& Religion, University of Tennessee \\ at Chattanooga, Chattanooga, Tennessee, USA \\ ethan-mills@utc.edu \\ Matthew Dasti \\ Department of Philosophy, Bridgewater State University, Bridgewater, \\ Massachusetts, USA \\ mdasti@bridgew.edu
}

\begin{abstract}
Introduces the topic of skepticism in Indian philosophy as well as the contents of a special issue of the International Journal for the Study of Skepticism: "Skepticism in India."
\end{abstract}

\section{Keywords}

skepticism - India - Nāgārjuna - Cārvāka - Jayarāśi - Śrīharṣa - Nyāya

Is skepticism in some sense a natural issue that arises whenever philosophical inquiry into knowledge takes place? If so, would one expect to see versions of skepticism across numerous philosophical traditions?

While these are large questions that go far beyond the scope of either this introduction or this special issue of the International Journal for the Study of Skepticism, we hope that the work represented here can become part of the inquiry into such questions. At the very least, we hope to dispel the myth that philosophical skepticism is a purely European or Western phenomenon. Skepticism is rather, as the title of this journal indicates, an international and indeed, intercultural phenomenon. 
The philosophical traditions of the Indian subcontinent are a vast and diverse buffet of philosophical offerings that ought to entice students of the history of philosophy. We hope that the present volume will constitute an invitation for those interested in philosophical skepticism to take a closer look at some intriguing and distinct skeptical challenges and anti-skeptical responses in the history of global philosophy.

While the papers included in this volume give more details about the history of philosophy in India, skeptical worries and responses can be identified as early as the Rg Veda (circa 1400-1000 BCE; see Mills 2018: 3-6), and persist though the contemporary period (see the final paper by Jay L. Garfield on A. C. Mukerji), with a long tradition in between. Dasti (2018) provides a more systematic overview of skepticism in the formative period of Indian philosophy.

There is also the intriguing question of the historical interactions between Greek and Indian skeptics in antiquity, raised most famously by Pyrrho's journey to South Asia with Alexander. While none of the papers here focus on this historical topic, the first paper, by Georges Dreyfus and Jay L. Garfield, includes resources for those interested in investigating further.

The name most associated with skepticism in the classical Indian tradition is the second-century CE philosopher Nāgārjuna, who is considered to be the founder of the Madhyamaka school of Buddhist philosophy. It should be noted that interpreting Nāgārjuna's dense and difficult texts is no small feat, and there are a variety of non-skeptical interpretations of his texts (including, but not limited to, interpretations that are anti-realist, mystical, deconstructionist, irrationalist, etc.). Acknowledging these scholarly disputes, the first paper, by Dreyfus and Garfield, develops a skeptical interpretation of Nāgārjuna that involves fascinating comparisons with Pyrrhonian skepticism, and the second paper, by Pradeep P. Gokhale, offers a slightly different interpretation of Nāgārjuna as a "cognitive skeptic." In his text Overturning the Objections (Vigrahavyāvaranī), Nāgārjuna set the tone for later skeptics by offering critiques of the bedrock of Indian epistemology: the means of knowledge (pramāna).

Gokhale also discusses two later philosophers: the materialist/skeptic Jayarāsi (circa 9th century CE) and the non-dualist Śrīharșa (circa 12th century $\mathrm{CE}$ ). While one might wonder how such a diverse group from distinct schools could all be skeptics, Gokhale argues that, despite their differences, Nāgārjuna, Jayarāśi, and Śrīharșa are united in their use of the methodology of "negative debate" (vitand $\bar{a}$ ), particularly targeting the means of knowledge.

The third paper, by Ethan Mills, looks at three different kinds of skepticism in the Cārvāka/Materialist tradition: a critique of the inference (anumāna) that is similar to Hume's problem of induction, a mitigated skepticism that 
allows empirically-based induction, and lastly Jayarāśi's radical skepticism, amplifying and developing some of the discussion by Gokhale.

For any active skeptics, one would expect anti-skeptics to respond, and we find this in the Indian tradition as particularly in the realist school of Nyāya (literally, "logic"), one of the major Brahmanical ("Hindu") traditions of thought. The fourth paper, by Kisor Kumar Chakrabarti, delves into Nyāya responses to major skeptical arguments.

Skeptical concerns are not limited to the classical or medieval Indian tradition (nor is creative work in "Indian Philosophy" the sole possession of classical thinkers). The last paper by Jay L. Garfield looks at the early 2oth century Indian philosopher A. C. Mukerji's consideration of skepticism about self-knowledge. Mukerji articulates the problem by drawing on diverse philosophical resources, including Hume, Kant, Hegel, and Buddhist philosophy, and he attempts to answer this problem via a novel, modern interpretation of the 8th century non-dualist philosopher Śankkara.

While none of the papers here provides a thorough overview of the entire history of skepticism in India - which would be a major task indeed! - we hope that these treatments of different skepticisms in different parts of the tradition will offer readers of this journal an entry point to further investigate the Indian contributions to skeptical thought.

In closing, we would like to thank the contributors for their diligence and patience during this longer-than-expected process and the co-editor of the International Journal for the Study of Skepticism, Diego E. Machuca, for his enthusiastic support and encouragement for this project. In addition to the vicissitudes that beset all collective publications, we also faced a pandemic and various personal challenges. As is perhaps appropriate for an issue on skepticism, we didn't know what was coming when Matthew Dasti first pitched the idea some time ago. But whether through luck, persistence, or sheer happenstance, we are pleased to offer this issue to readers of the International Journal for the Study of Skepticism.

\section{References}

Dasti, Matthew R. 2018. "Skepticism in Classical Indian Philosophy." In D. E. Machuca \& B. Reed (ed.), Skepticism: From Antiquity to Present, 145-161. London: Bloomsbury Academic.

Mills, Ethan. 2018. Three Pillars of Skepticism in Classical India: Nāgārjuna, Jayarāsisi, and Śrī Harșa. Lanham, MD: Lexington Books. 